\title{
Demonstration of Nuclear and Cellular Division in Bacillus cereus by Epifluorescent Microscopy
}

\author{
By K. A. BISSET AND HILARY WHITBY \\ Department of Bacteriology, University of Birmingham, \\ Birmingham B15 2TJ
}

(Received 1 March 1978)

Division of the nucleus and the cellular structure of bacteria may be correlated by using epifluorescent filter systems on acridine orange-stained material. The high resolution enables the spatial arrangement of double elements in the nucleus of Bacillus cereus to be visualized, after minimal handling, for comparison with information obtained by other methods.

\section{INTRODUCTION}

It is well known that although bacteria have a superficial appearance of surviving gross mishandling, for example heat-fixation and staining by the methods of Gram or ZiehlNeelsen, the details of the cellular and nuclear structure are exceptionally liable to damage and distortion unless material is treated with great care during its preparation (see Bisset, 1970, for references). The appearance of the nucleus may be altered completely in microscopic preparations by relatively small changes in the ionic environment (Whitfield \& Murray, 1956), and no such preparation would survive unaltered the relatively violent methods involved in dehydration and embedding for electron microscopy of sections. It is almost impossible to correlate the appearances seen in the best electron micrographs of sections with those of the nucleus in stained preparations with much less mechanical interference (see Bisset, 1970, for references), or in living material by phase contrast (Mason \& Powelson, 1956). The great advances that have been made in our knowledge of the processes of nuclear reproduction in bacteria have provided remarkably little direct information about the actual morphology of the nucleus except by inference. Photomicrographs of unicellular enterobacteria in the process of division, of a very high standard of clarity, have been available for many years (Robinow, 1945). The nucleus is a discrete, short rod, undergoing what appears to be a simple fission process. However, the nucleus of sporing bacilli, much studied because of the presence of numerous mesosomes, at the points of cell division, with which the replication system appears to be associated (Ryter \& Jacob, 1964), may be a more complex organelle. This has not been so clearly figured despite many attempts (e.g. Fitz-James, 1954), partly because it is not easy to demonstrate simultaneously the nucleus and the cellular structure of the bacillus. It is therefore difficult to determine whether the elements in question are associated with one or more cells. This was understood by Robinow (1945) who made parallel preparations of different cells by nuclear and cell wall stains. His work has not been improved upon.

This paper describes a simple method whereby material that has been subjected to minimal treatment may be examined simultaneously for the behaviour of the nuclear and cellular structures at division, by fluorescence in ultraviolet light of bacteria stained with acridine orange. The method was previously attempted by Krieg $(1954 a, b, c, d)$ but the results were unsatisfactory, partly because of the failure to understand the problem of 

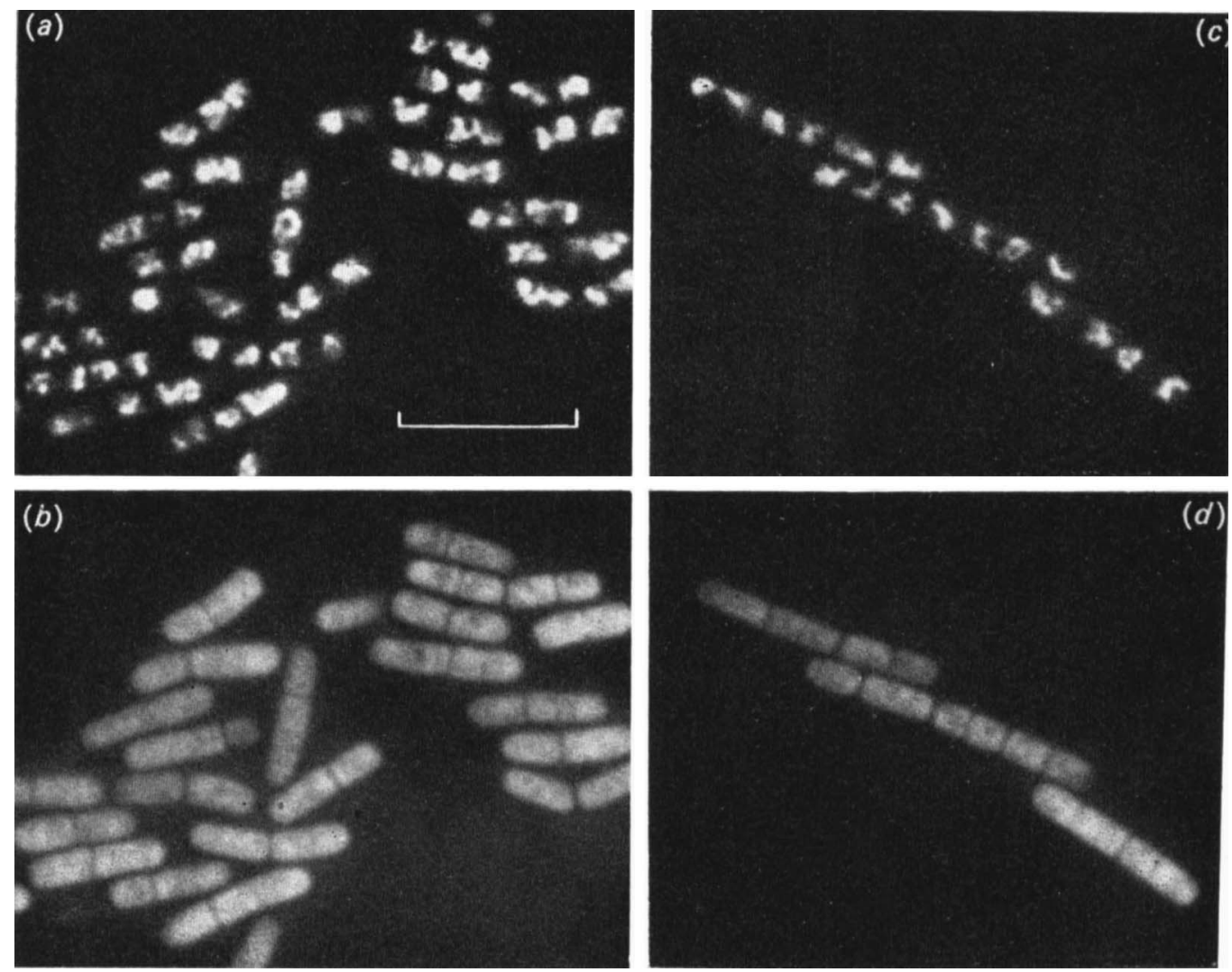

Fig. 1. Bacillus cereus var. mycoides stained by acridine orange and illuminated by epifluorescent ultraviolet light. (a) Nuclear bodies under blue excitation (DNA) after $1 \mathrm{~h}$ incubation. (b) Same field as (a) showing cell structure by green excitation (RNA). (c) Nuclear bodies after $4 \mathrm{~h}$ incubation. (d) Same field as (c) showing cell structure. Bar marker represents $8 \mu \mathrm{m}$.

multicellularity in bacteria. The dye fluoresces in the presence of nucleic acids, with colour differentiation between DNA and RNA, which are preponderant in the nuclear and outer regions of bacteria, respectively, and can readily be distinguished by colour filtration. Although proof is lacking, the short-wave illumination may also provide advantages in resolution, even when it is visible light that provides the images. Comparison of the nuclear and cell figures allows a reconstruction to be made that shows certain differences between the nucleus of Bacillus cereus and the better known, and probably simpler, structure seen in enterobacteria.

\section{METHODS}

The photomicrographs are of a strain of Bacillus cereus (var. mycoides) isolated in this laboratory and chosen because of its large size and satisfactory photomicrographic qualities. The technique was also applied to strains of Escherichia coli, Proteus vulgaris and Proteus mirabilis for comparison, to ensure that the organelles demonstrated were comparable with the known nucleoids of such bacteria.

Cultures were grown on Trypticase Soy Agar (Difco) at $37^{\circ} \mathrm{C}$ for 1 to $5 \mathrm{~h}$ after inoculation from an overnight culture. A piece of agar bearing growth was cut out, smeared across a clean coverslip, air-dried for a few seconds, immersed in acetate buffer pH 4.2 (Chayen et al., 1973) for $5 \mathrm{~min}$, and transferred to a solution of acridine orange $(1: 10000, \mathrm{w} / \mathrm{v}$, in buffer) for 15 to $30 \mathrm{~min}$. It was then washed and mounted in buffer under a coverslip sealed with beeswax. Photomicrographs were made by means of a Zeiss epifluorescent microscope using the blue excitation system for visualizing the nucleus (KP500, KP490 interference; FT510 splitter) and the green excitation system for the cell envelopes and remainder of the cell components (BP546 interference; FT580 splitter) (Zeiss $\times 120,1.3 \mathrm{~mm}$ apochromatic lens, Holos $\times 20$ compensable, draw-tube ocular). Exposures were of 10 to 30 s using Ilford HP4 film (ASA 400 to 650). 

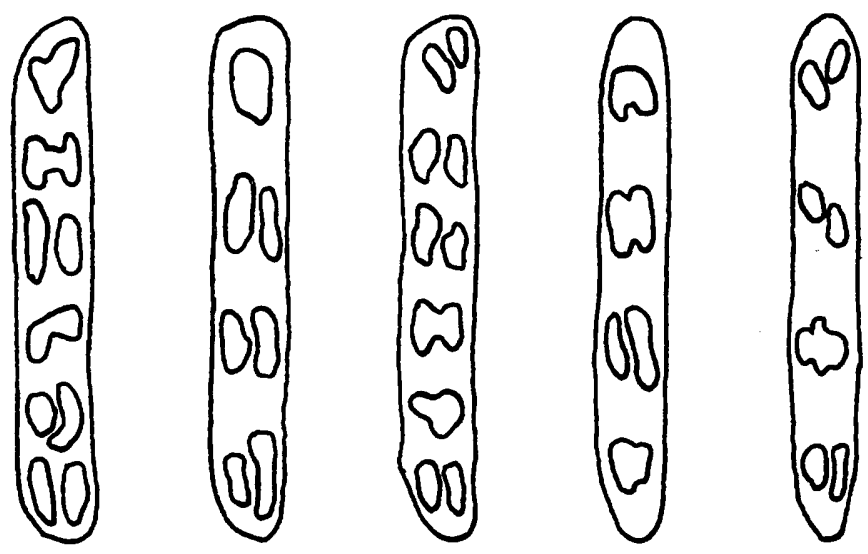

Fig. 2. Drawings made directly from acridine orange-stained preparations of Bacillus cereus var. mycoides showing nuclear bodies by epifluorescent blue excitation (DNA). The nucleoids appear to lie in pairs across the long axis. Cell boundaries are not shown.

\section{RESULTS}

Figure 1 shows the results of using this method on cultures aged $1 \mathrm{~h}(a, b)$ and $4 \mathrm{~h}(c, d)$. The nuclear material fluorescing as DNA under the blue excitation system was very pale green (Fig. $1 a, c$ ); the cellular structure under the green excitation was orange-red (Fig. $1 b$, d). Immediate comparison could be made between the appearance of the nucleus and the remainder of the cell by switching the filter system.

The nucleoids appeared as small, discrete, short rods, lying at various angles one to the other, and frequently as pairs across the diameter of the bacillus. In contrast, the dividing nucleoids of the enterobacteria were in pairs oriented as if dividing with the long axis of the bacterium; this was clearly seen in the Proteus spp. and E. coli. Occasional nuclear structures giving the well known but fallacious impression of spiral rods, lying longitudinally in the bacillus, could also be seen (see Bisset, 1970, for references). However, by use of the two methods of viewing, combined with differential focusing, these were resolvable as separate bodies, and usually as parts of more than one cell. Figure 2 shows sketches made independently by three undergraduates from microscopic preparations in situ, similar to those in Fig. 1, without any guidance as to what they should expect to see. The sketches showing discrete nuclear bodies were recopied by one of them, in format. The tendency of the nucleoids to appear in pairs across, rather than along, the bacillus is clearly indicated.

The main differences between the younger and older cultures were that both nucleoids and cell plasm fluoresced more brightly and appeared slightly more bulky in the former, whereas the separation between individual cellular units was more marked in the latter, which were presumably in the exponential rather than the lag phase.

\section{DISCUSSION}

The method described has the advantages of giving a clear picture of both nucleus and cellular organization, with so little handling of the bacteria that their natural appearance is probably preserved. The forms observed closely resemble those of the nucleoids of Bacillus demonstrated in phase contrast of living material by Mason \& Powelson (1956), but there is much greater clarity by this method. They do not exactly correspond to appearances shown by the $\mathrm{HCl}-\mathrm{Giemsa}$ technique (see Bisset, 1970, for references) nor to more detailed, hypothetical reconstructions such as that of Fitz-James (1954). The general impression is that the nucleus of Bacillus cereus is not a single but a double body. The 
orientation of the components indicates that they may not be sisters, as they are in the better known double body in Enterobacteria. It is suggested that the interpretation of the bacterial nucleus based upon electron microscopy of sections can only be accepted so far as it is in accordance with such visual appearances in relatively unharmed material.

We wish to thank Gillian Pickford and P.-T. Chan, who made the sketches, and especially Linda Sibley, who also redrew the figure.

\section{REFERENCES}

Bisset, K. A. (1970). The Cytology and Life-history of Bacteria, 3rd edn. Edinburgh \& London: Livingstone.

ChAYen, J., BITENSKy, L. \& ButcheR, R. G. (1973). Practical Histochemistry, revised edn. Chichester: Wiley.

FITZ-JAMES, P. C. (1954). The duplication of bacterial chromatin. Journal of Bacteriology 68, 464-473.

KRIEG, A. (1954a). Nachweis kernäquivalenter Strukturen bei Bakterien in vivo. I. Zeitschrift für Hygiene und Infektionskrankheiten 138, 357-363.

KRIEG, A. (1954b). Nachweis kernäquivalenter Strukturen bei Bakterien in vivo. II. Zeitschrift für Hygiene und Infektionskrankheiten 138, 530534.

KRIEG, A. (1954c). Nachweis von Kernäquivalenten bei Bakterien in vivo. III. Zeitschrift für Hygiene und Infektionskrankheiten 139, 61-63.
KrIEG, A. (1954d). Nachweis von Kernäquivalenten bei Bakterien in vivo. IV. Zeitschrift für Hygiene und Infektionskrankheiten 139, 64-68.

Mason, D. J. \& Powelson, D. M. (1956). Nuclear division as observed in live bacteria by a new technique. Journal of Bacteriology 71, 474-479.

RoBINOw, C. F. (1945). Addendum. In The Bacterial Cell, by R. J. Dubos. Cambridge, Mass.: Harvard University Press.

RYTER, A. \& JACOB, F. (1964). Étude au microscope électronique de la liaison entre noyau et mésosome chez Bacillus subtilis. Annales de l'Institut Pasteur 107, 384-400.

WhitField, J. F. \& MurRay, R. G. E. (1956). The effects of the ionic environment on the chromatin structures of bacteria. Canadian Journal of Microbiology 2, 245-260. 